\title{
Proteomic analysis reveals the diversity and complexity of membrane proteins in chickpea (Cicer arietinum L.)
}

\author{
Dinesh Kumar Jaiswal, Doel Ray ${ }^{\dagger}$, Pratigya Subba ${ }^{\dagger}$, Poonam Mishra, Saurabh Gayali, Asis Datta, \\ Subhra Chakraborty and Niranjan Chakraborty*
}

\begin{abstract}
Background: Compartmentalization is a unique feature of eukaryotes that helps in maintaining cellular homeostasis not only in intra- and inter-organellar context, but also between the cells and the external environment. Plant cells are highly compartmentalized with a complex metabolic network governing various cellular events. The membranes are the most important constituents in such compartmentalization, and membrane-associated proteins play diverse roles in many cellular processes besides being part of integral component of many signaling cascades.

Results: To obtain valuable insight into the dynamic repertoire of membrane proteins, we have developed a proteome reference map of a grain legume, chickpea, using two-dimensional gel electrophoresis. MALDI-TOF/TOF and LC-ESI-MS/MS analysis led to the identification of 91 proteins involved in a variety of cellular functions viz., bioenergy, stress-responsive and signal transduction, metabolism, protein synthesis and degradation, among others. Significantly, $70 \%$ of the identified proteins are putative integral membrane proteins, possessing transmembrane domains.

Conclusions: The proteomic analysis revealed many resident integral membrane proteins as well as membrane-associated proteins including those not reported earlier. To our knowledge, this is the first report of membrane proteome from aerial tissues of a crop plant. The findings may provide a better understanding of the biochemical machinery of the plant membranes at the molecular level that might help in functional genomics studies of different developmental pathways and stress-responses.
\end{abstract}

Keywords: Grain legume, Membrane-associated proteins, 2-DE, Mass spectrometry, Transmembrane domain

\section{Background}

Membranes are highly organized structures specially adapted to perform multiple functions in eukaryotic cells. They constitute the interface between the various cellular compartments and play a critical role in the exchange of substances and signals. Cell membranes consist of dynamic lipid-protein matrices wherein the lipid component provides a barrier to solute movement, and membrane-associated proteins perform unique biological roles in development as well as stress adaptation.

\footnotetext{
* Correspondence: nchakraborty@nipgr.res.in

${ }^{\dagger}$ Equal contributors

National Institute of Plant Genome Research, JNU Campus, Aruna Asaf Ali Marg, New Delhi, 110067, India
}

The composition and dynamics of membrane proteins reflect their diverse function, and their nature and relative amount vary from one organellar membrane to another. The membranes associated with different organelles not only play important roles in maintaining the homeostasis within organelles, but also at the whole cell level. Approximately $30 \%$ of the cellular proteome is represented by membrane proteins [1]. These proteins perform some of the most important functions, including the regulation of cell signaling, cell-cell interactions, and intracellular compartmentalization [2].

Due to the presence of highly specialized organelles such as plastids and vacuoles, the plant membrane proteome is more complex compared to that of animal

\section{Biomed Central}


cells. The pivotal role played by membrane proteins in many cellular processes makes their study imperative. However, the proteomic analysis of membrane proteins has always been hampered due to their recalcitrance to standard methodologies [3]. Indeed, membrane proteins are under-represented in large-scale proteomics and are challenging to work with. The proteomic analysis of membrane proteins has been impeded due to their hydrophobic nature, lesser abundance and physicochemical heterogeneity [4]. While much progress has been made in animal membrane proteomics, far fewer attempts have been made to characterize the plant membrane proteome [5-8].

Legumes are valuable agricultural crops that serve as important nutrient sources for human diet and animal feed worldwide. They serve as an important protein-rich food and have increasingly become a commercial commodity. The members of this family have unique features such as biological nitrogen fixation and symbioses with mycorrhizal fungi [9], which make them good experimental models for various studies. Chickpea is the most important grain legume and ranks third in terms of total global production $[10,11]$. The world's total production of chickpea hovers around 8.5 million metric tons annually and is grown over 10 million hectares of land. Despite the importance of chickpea and its role in nutrition requirement in humans, it has remained outside the realm of large-scale functional genomics studies. Although in recent years, much attention has been given to chickpea genomics [12-16], there is still little information on its protein complement. In previous proteomic studies, we had developed an extracellular matrix- and nucleus-specific proteome of chickpea $[17,18]$. We report here the development of membrane proteome with an aim to use the reference map for more comprehensive characterization of the regulation and function of membrane proteins. Over 300 proteins were resolved using two-dimensional gel electrophoresis (2-DE), and MALDI-TOF/TOF and LCESI-MS/MS techniques were used to identify the proteins. The identified proteins were classified on the basis of their putative functions. Membrane-association of the identified proteins was validated by assessing their hydropathicity and the presence of transmembrane domains (TMDs). It is notable that $\sim 70 \%$ of the dataset were predicted to be integral membrane proteins, which is considerably higher than other gel-based membrane proteomic analyses thus far. We have identified many candidates that are integral membrane proteins as well as membrane-associated proteins including those not reported earlier. This study may facilitate comparative proteomics as well as functional genomics studies of plant development and adaptation to various stresses.

\section{Results and discussion}

\section{Isolation of membrane proteins}

The fractionation and selective enrichment of the microsomal fraction of chickpea was accomplished by differential centrifugation. It was systematically assessed for the enrichment of various subcellular membranous components using standard marker enzyme assays viz., vanadate-, azide-, nitrate-sensitive ATPase and latent IDPase for plasma membrane, mitochondrial membrane, tonoplast and Golgi membranes, respectively. The relative change in percent inhibition of ATPase activity associated with mitochondria and tonoplast was 2.29 and 1.68 fold, respectively in microsomal fraction compared to the crude homogenate (Figure $1 \mathrm{~A}$ and $\mathrm{B}$ ). Further, increase in relative fold-change in percent activity of latent IDPase in microsomal fraction was $\sim 1.5$ (Figure $1 \mathrm{C}$ ). For plasma membrane ATPase, $\mathrm{K}^{+}$-stimulated increase in the percent activity was 1.68 fold, while vanadate-sensitive inhibition was 1.72 fold (Figure 1D). The activity of vanadate-sensitive ATPase could not be compared with crude homogenate as it had $\mathrm{pH} 8.0$ and the assay was performed at $\mathrm{pH}$ 6.5. The higher level of activities of the marker enzymes in the membrane fraction indicates the enrichment of various subcellular membranous components.

Major bottlenecks of membrane proteomics are the poor solubility and low abundance of the proteins, which limit their detection and identification. In this study, we focused on identification of the whole set of membrane proteins, including integral membrane proteins as well as peripheral membrane-associated proteins. It is understood that due to their physicochemical heterogeneity, there is no one-fit-all protocol for the extraction, solubilization, and separation of membrane proteins [19]. In order to achieve maximum representation of membrane proteins in one extraction procedure, we extracted the proteins using various ratios of chloroform/ methanol. The proteins extracted from the insoluble pellet and soluble fraction (after acetone precipitation) corresponding to each chloroform/methanol ratio were then subjected to 1-D SDS-PAGE. While the insoluble proteins obtained from each chloroform/methanol extraction showed similar profile (Figure 2A), the proteins precipitated from their corresponding organic phase showed differential profile (Figure $2 \mathrm{~B}$ ). The presence of phytopigments viz., chlorophyll-a, b and carotenoids was also examined. The insoluble proteins obtained from 6:3 ratio of organic mixture was least green when compared to the others, which is corroborated by the content of contaminating phytopigments being maximal in its organic phase (Figure 2C). Taken together, these results suggest that 6:3 ratio of chloroform/methanol is optimal considering the maximal extraction of membrane proteins with least 

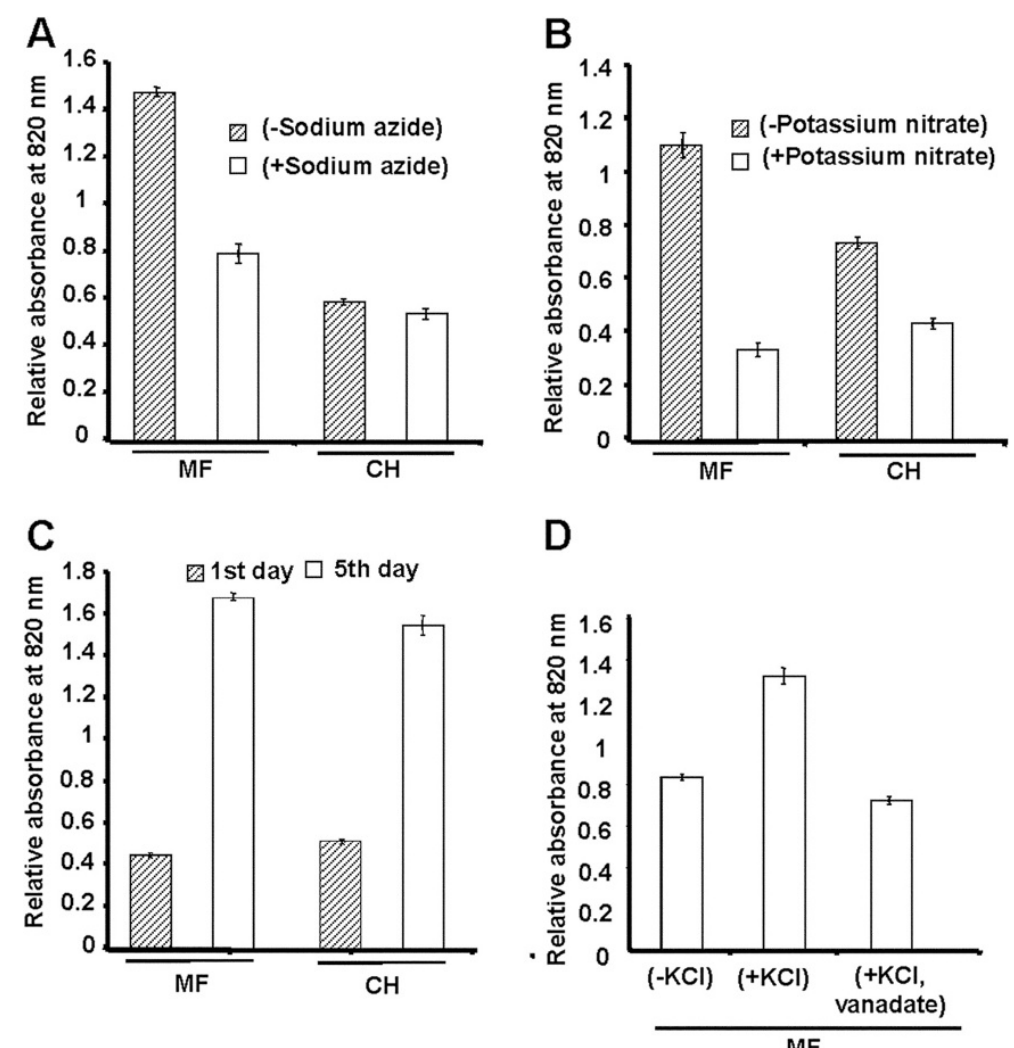

Figure 1 Enzymatic Characterization of the Membrane Fraction. The activities of marker enzymes associated with different organellar membranes were determined by spectrophotometric method. (A) Sodium azide-sensitive ATPase (mitochondrial membrane), (B) Potassium nitrate-sensitive ATPase (tonoplast), (C) Latent IDPase (Golgi membrane), and (D) K ${ }^{+}$-stimulated and sodium orthovanadate sensitive ATPase (plasma membrane). MF represents the membrane fraction, while $\mathrm{CH}$ represents the crude homogenate. All experiments were carried out in triplicates with at least two biological samples and average mean values were plotted against individual fractions.

phytopigments contamination. The proteins from the corresponding pellet fraction were used to perform 2-DE.

\section{Development of membrane proteome}

To optimize the 2-DE membrane protein separation and resolution, several technical modifications were attempted. Electrofocusing of membrane proteins was performed using different IPG strips ( $\mathrm{pH} \mathrm{3-10} \mathrm{and} \mathrm{4-7)}$ and various sample-loading methods viz. in-gel rehydration or cup sample loading at the anodic or at the cathodic end of the strips. The proteins were well resolved in cup sample loading at the anodic end with maximum representation of spots in the $\mathrm{pH}$ range of 4-7 (Figure $3 \mathrm{~A}$ and $\mathrm{B}$, Additional file 1. Figure $\mathrm{S} 1$ ). The experiments were performed with at least two biological and three technical replicates. Positional reproducibility in 2-DE was determined by PDQuest analysis that led to the detection of over 300 protein spots of which 280 spots were highly reproducible. The spots were screened with various stringent filtration criteria including spot quality score ( $>30)$. MS/MS analysis led to the identification of 91 proteins with high confidence, which is listed in Table 1. The spots are designated as CaM-X, where $\mathrm{Ca}$ indicates the organism (icer arietinum), and $\mathrm{M}$ indicates the fraction (membrane) while numerals indicate the spot numbers.

\section{Physicochemical characteristics of membrane proteins}

To examine putative characteristic features of the proteome, the identified proteins were analysed with respect to molecular mass and $\mathrm{pI}$ distribution. The $\mathrm{pI}$ of the proteins identified in chickpea ranges from 4 to 7 (Figure 4A). This distribution is not radically different from that of Medicago with $85 \%$ proteins distributed in similar pI range [20]. However, a comparison with that of white lupin indicated slight differences with $55 \%$ basic proteins $(\mathrm{pI}>7)$ [21]. The molecular masses of proteins identified ranged from 10 to $90 \mathrm{kDa}$, with majority of proteins $(\sim 80 \%)$ exhibiting a molecular mass between 20 and $60 \mathrm{kDa}$ (Figure 4B). This seems to be a relatively classical feature of legume membrane proteins.

To evaluate the physicochemical characteristics of the chickpea membrane proteins, the whole dataset was analysed in terms of hydrophobicity (grand average of 


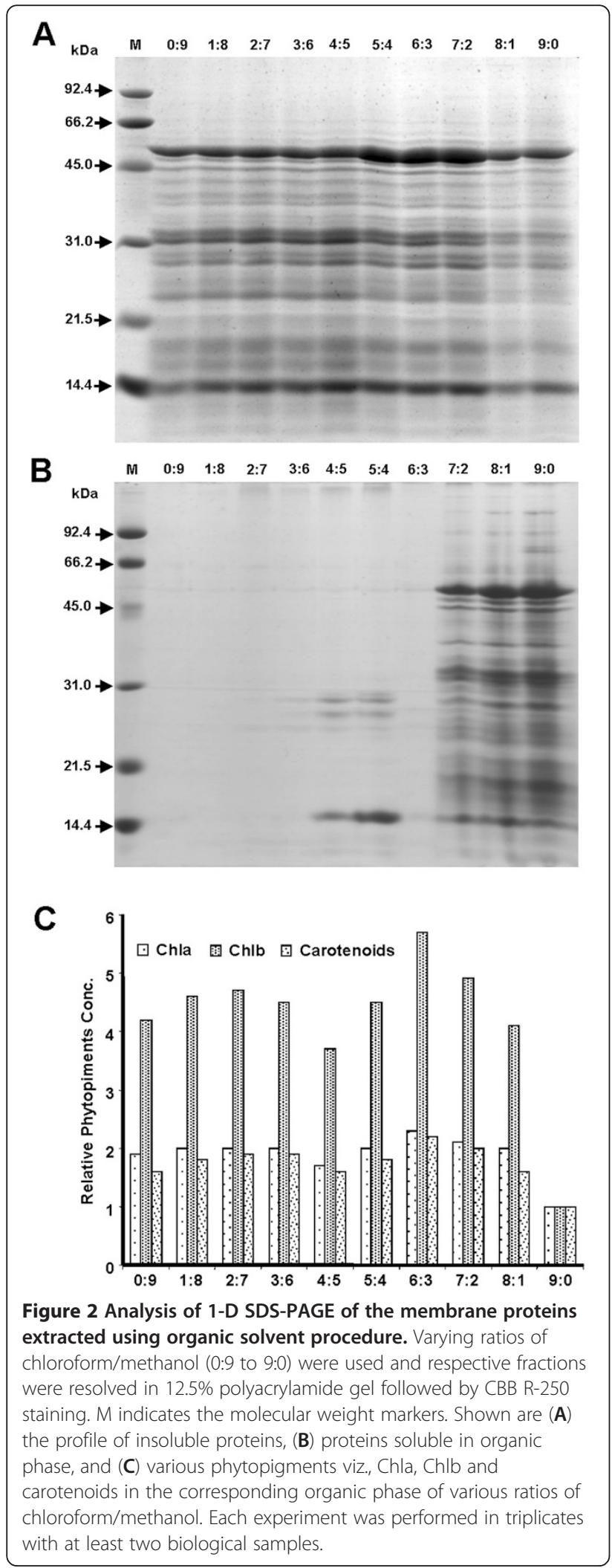

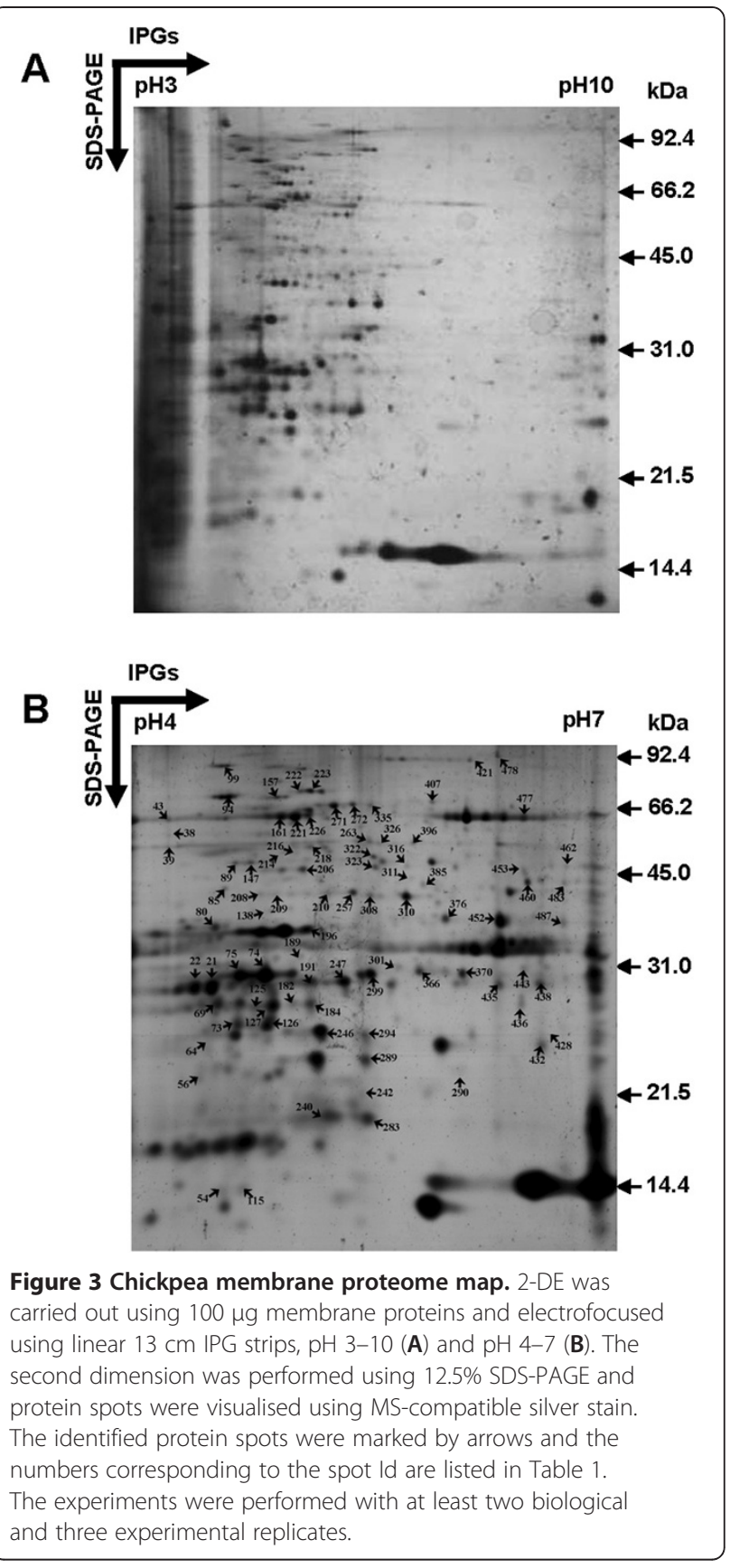

hydropathicity, GRAVY values) and membrane localization vis-à-vis the presence of TMDs. The modular structure of membrane proteins consist of hydrophobic domains and hydrophilic loops or termini. The hydrophobic regions are involved in the formation of TMDs that may be $\alpha$-helices or $\beta$-barrels, deeply buried in the lipid bilayer [22]. Five different prediction programs were used to predict putative TMDs in the identified proteins (Additional file 2. Table S1). Figure 5A shows the distribution of identified proteins with one or multiple membrane-spanning domains. Significantly, $70 \%$ of 
Table 1 Proteins identified in membrane fraction using 2-DE coupled with MS/MS analysis

\begin{tabular}{|c|c|c|c|c|c|c|c|c|c|}
\hline Functional Category & Spot No. ${ }^{a}$ & Identification & Score & gi No. ${ }^{b}$ & $N P^{c}$ & $\begin{array}{l}\text { GRAVY } \\
\text { Value }^{\text {d }}\end{array}$ & \% Coverage & $\begin{array}{c}\text { Theoretical } \\
\mathrm{MW} / \mathrm{pl}\end{array}$ & $\begin{array}{c}\text { Experimental } \\
\mathrm{MW} / \mathrm{pl}\end{array}$ \\
\hline \multirow[t]{18}{*}{ Signaling and stress response } & CaM-89* & Serine threonine kinase homolog COK-4 & 48 & 9796478 & 2 & -0.036 & 5 & $42.25 / 6.42$ & $44.78 / 4.74$ \\
\hline & CaM-246! & Putative serine/threonine kinase & 71 & 110289142 & 11 & -0.526 & 25 & $50.40 / 9.89$ & $25.76 / 5.30$ \\
\hline & CaM-247 & Membrane protein $\mathrm{CH} 1$-like & 41 & 115441379 & 3 & -0.510 & 2 & $70.30 / 4.91$ & $30.04 / 5.45$ \\
\hline & CaM-85! & Calcineurin-like phospho-esterase family protein & 63 & 22329383 & 11 & -0.370 & 29 & $43.99 / 5.36$ & $42.64 / 4.72$ \\
\hline & CaM-436* & Putative quinone oxidoreductase & 158 & 21068664 & 4 & -0.124 & 25 & $21.70 / 6.51$ & $28.26 / 6.62$ \\
\hline & $\mathrm{CaM}-73^{*}$ & Actin (Fragment) & 63 & 111610552 & 1 & -0.165 & 7 & $23.51 / 4.78$ & $26.43 / 4.75$ \\
\hline & $\mathrm{CaM}-428^{*}$ & Beta-1,3-glucanase & 80 & 116490100 & 1 & 0.060 & 3 & $36.41 / 8.82$ & $24.77 / 6.75$ \\
\hline & CaM-182* & Ferritin $^{\mathrm{e}}$ & 50 & 224140479 & 1 & -0.284 & 6 & $16.58 / 5.14$ & $28.10 / 5.12$ \\
\hline & $\mathrm{CaM}-487^{*}$ & Guanine nucleotide-binding protein subunit beta-like & 297 & 3023847 & 7 & -0.153 & 30 & $31.83 / 6.44$ & $36.41 / 6.89$ \\
\hline & CaM-191* & Ferritin $^{\mathrm{e}}$ & 129 & 255637227 & 2 & -0.297 & 9 & $30.24 / 5.23$ & $30.24 / 5.23$ \\
\hline & CaM-326 & Cytochrome P450 & 32 & 15238866 & 2 & -0.218 & 4 & $58.91 / 7.98$ & $52.62 / 5.68$ \\
\hline & CaM-432- & Disease resistance protein (Fragment) & 32 & 108739945 & 2 & -0.119 & 4 & $23.29 / 6.10$ & $21.25 / 6.62$ \\
\hline & CaM-94* & Chaperonin 60 alpha $^{f}$ subunit & 764 & 217074850 & 17 & 0.004 & 28 & $62.02 / 5.11$ & $72.03 / 4.7$ \\
\hline & CaM-99* & Chaperone DnaK & 501 & 92870233 & 11 & -0.330 & 15 & $75.71 / 5.19$ & 83.09/4.69 \\
\hline & CaM-483* & Luminal binding protein, BiP & 248 & 297742397 & 7 & -0.374 & 6 & $73.31 / 4.96$ & $30.25 / 6.91$ \\
\hline & CaM-157* & Putative GloEL protein Chaperonin 60 kDa & 192 & 225435794 & 4 & -0.094 & 38 & $17.51 / 10.05$ & $45.83 / 5.00$ \\
\hline & CaM-150! & Chaperonin 60 alpha $^{f}$ subunit & 108 & 3790441 & 12 & 0.001 & 13 & $61.45 / 5.23$ & $57.09 / 5.12$ \\
\hline & $\mathrm{CaM}-421 \uparrow$ & Chaperonin 60 alpha $^{f}$ chain precursor, & 78 & 1710807 & 4 & -0.025 & 7 & $61.99 / 5.15$ & $85.92 / 6.28$ \\
\hline \multirow[t]{9}{*}{ Protein synthesis and degradation } & $\mathrm{CaM}-39^{*}$ & Putative 605 ribosomal protein $\mathrm{L} 1$ & 101 & 84468414 & 3 & -0.445 & 7 & $44.93 / 10.40$ & $51.00 / 4.29$ \\
\hline & $\mathrm{CaM}-240^{*}$ & $40 S$ ribosomal protein $\$ 12$ & 54 & 255626071 & 2 & 0.106 & 12 & $15.34 / 5.50$ & 19.26/5.37 \\
\hline & CaM-283* & $40 S$ ribosomal protein $\mathrm{S} 12$ & 162 & 255626071 & 3 & 0.106 & 23 & $15.345 / 5.50$ & 19.02/5.607 \\
\hline & CaM-223! & Putative glutamate-tRNA ligase & 70 & 115443869 & 14 & -0.304 & 11 & $63.10 / 6.27$ & $74.10 / 5.23$ \\
\hline & CaM-208* & Putative 605 acidic ribosomal protein P0 & 89 & 84468360 & 2 & 0.031 & 7 & $34.31 / 5.27$ & $40.24 / 5.10$ \\
\hline & CaM-209* & Putative 605 acidic ribosomal protein P0 & 82 & 84468360 & 2 & 0.031 & 7 & $34.31 / 5.27$ & $40.25 / 5.21$ \\
\hline & $\mathrm{CaM}-301^{*}$ & Proteasome subunit alpha type & 199 & 224139394 & 4 & -0.227 & 21 & $27.38 / 5.59$ & $31.39 / 5.81$ \\
\hline & CaM-249! & Polyubiquitin & 64 & 18421671 & 10 & -0.281 & 27 & $36.40 / 5.83$ & $28.56 / 5.47$ \\
\hline & CaM-407! & Mitochondrial processing peptidase beta subunit & 394 & 12802327 & 20 & -0.302 & 22 & $58.90 / 6.56$ & $70.46 / 6.03$ \\
\hline
\end{tabular}


Table 1 Proteins identified in membrane fraction using 2-DE coupled with MS/MS analysis (Continued)

\begin{tabular}{|c|c|c|c|c|c|c|c|c|c|}
\hline \multirow[t]{30}{*}{ Bioenergy } & $\mathrm{CaM}-242^{*}$ & Cytochrome b6-f complex iron-sulfur subunit & 76 & 136707 & 2 & -0.039 & 15 & $16.85 / 6.45$ & $22.19 / 5.53$ \\
\hline & CaM-21! & Chlorophyll a/b-binding ${ }^{9}$ protein AB96 & 224 & 115773 & 9 & 0.011 & 22 & $24.36 / 4.98$ & $29.51 / 4.58$ \\
\hline & $\mathrm{CaM}-75^{*}$ & Chlorophyll a/b binding ${ }^{9}$ protein & 411 & 3928140 & 12 & -0.068 & 30 & $28.35 / 5.47$ & $30.58 / 4.78$ \\
\hline & CaM-196* & Oxygen-evolving enhancer protein $1^{\mathrm{h}}$ & 177 & 131384 & 6 & -0.303 & 15 & $35.44 / 5.19$ & $35.44 / 5.19$ \\
\hline & CaM-294* & Putative PSII-P protein & 104 & 217072770 & 2 & -0.273 & 8 & $28.41 / 7.12$ & $25.41 / 5.59$ \\
\hline & CaM-22! & Chlorophyll a/b-binding protein 3 precursor $^{9}$ & 160 & 115800 & 7 & 0.005 & 19 & $27.90 / 5.46$ & $29.38 / 4.47$ \\
\hline & CaM-69! & Chlorophyll A-B binding protein ${ }^{9}$ & 118 & 169124051 & 8 & 0.071 & 12 & $28.59 / 5.44$ & $28.05 / 4.62$ \\
\hline & CaM-126! & Chlorophyll a/b-binding protein type III (Fragment) ${ }^{9}$ & 65 & 7271947 & 4 & -0.013 & 9 & $20.81 / 5.17$ & $26.40 / 4.95$ \\
\hline & CaM-127! & PSI type III chlorophyll a/b-binding protein (imported) & 99 & 15219941 & 7 & -0.014 & 11 & $29.16 / 8.61$ & $27.98 / 4.98$ \\
\hline & CaM-125! & Oxygen-evolving enhancer protein $1^{\mathrm{h}}$ & 111 & 131384 & 7 & -0.303 & 14 & $35.10 / 6.25$ & $27.83 / 4.87$ \\
\hline & CaM-183! & Oxygen-evolving enhancer protein 2 & 89 & 131390 & 9 & -0.312 & 14 & $28.20 / 8.29$ & $25.64 / 5.16$ \\
\hline & CaM-376* & Ferredoxin NADP reductase & 81 & 125553745 & 2 & -0.340 & 5 & $39.95 / 8.72$ & $36.9 / 6.12$ \\
\hline & CaM-184 & LHCA3, chlorophyll binding & 58 & 79320443 & 4 & -0.009 & 18 & $23.84 / 5.62$ & $28.07 / 5.23$ \\
\hline & CaM-74! & Light-harvesting chlorophyll-a/b binding protein Lhcb1 & 387 & 56809379 & 13 & -0.083 & 19 & $28.43 / 5.48$ & $30.58 / 4.93$ \\
\hline & CaM-319! & Putative ferredoxin-NADP $(H)$ oxidoreductase & 67 & 41052915 & 7 & -0.383 & 19 & $41.09 / 7.98$ & $39.76 / 5.92$ \\
\hline & CaM-452 & Ferredoxin: NADP + reductase & 130 & 4930119 & 3 & -0.403 & 12 & $34.98 / 6.54$ & $36.58 / 6.49$ \\
\hline & CaM-226! & ATPase beta subunit (Fragment) ${ }^{i}$ & 276 & 6467935 & 18 & -0.026 & 27 & $51.53 / 5.22$ & $65.89 / 5.21$ \\
\hline & CaM-147* & ATP synthase subunit beta, chloroplastic ${ }^{i}$ & 92 & 11466372 & 2 & 0.007 & 6 & $51.99 / 5.10$ & $44.87 / 4.84$ \\
\hline & CaM-189* & ATP synthase subunit alphaj & 589 & 197294119 & 18 & -0.057 & 24 & $55.64 / 5.44$ & $32.38 / 5.16$ \\
\hline & CaM-221! & ATP synthase beta subunit (Fragment) ${ }^{i}$ & 116 & 3850926 & 13 & 0.001 & 22 & $52.73 / 5.15$ & $65.80 / 5.14$ \\
\hline & CaM-161! & ATP synthase beta subunit (Fragment) ${ }^{i}$ & 918 & 7708546 & 41 & 0.004 & 51 & $51.18 / 5.07$ & $65.76 / 5.04$ \\
\hline & CaM-80! & ATP synthase beta subunit (Fragment) ${ }^{i}$ & 671 & 4063542 & 19 & 0.009 & 26 & $49.13 / 5.06$ & $35.75 / 4.60$ \\
\hline & CaM-316* & ATP synthase subunit alpha ${ }^{j}$ & 328 & 197294119 & 10 & -0.057 & 17 & $55.64 / 5.44$ & $45.62 / 5.83$ \\
\hline & $\mathrm{CaM}-222^{*}$ & ATP synthase subunit beta ${ }^{i}$ & 410 & 197294097 & 19 & -0.016 & 27 & $52.96 / 5.16$ & $73.99 / 5.16$ \\
\hline & CaM-335* & ATP synthase subunit alphaj & 75 & 197294119 & 2 & -0.057 & 4 & $55.64 / 5.44$ & $69.22 / 5.62$ \\
\hline & CaM-385 & ATP synthase subunit gamma, chloroplast precursor & 77 & 226533016 & 1 & -0.143 & 3 & $40.10 / 8.44$ & $41.00 / 6.06$ \\
\hline & $\mathrm{CaM}-311^{*}$ & ATP synthase CF1 alpha subunit' & 295 & 289066833 & 5 & -0.045 & 11 & $55.73 / 5.21$ & $42.49 / 5.89$ \\
\hline & CaM-396* & ATP synthase subunit alphaj & 439 & 197294119 & 10 & -0.057 & 19 & $55.64 / 5.44$ & $52.90 / 5.91$ \\
\hline & CaM-272! & ATP synthase CF1 alpha subunit' & 572 & 13518443 & 21 & -0.055 & 23 & $55.80 / 5.22$ & $69.51 / 5.51$ \\
\hline & CaM-271! & $\mathrm{H}+-$ transporting two-sector ATPase alpha chain & 83 & 114522 & 13 & -0.044 & 21 & $54.64 / 5.75$ & $69.09 / 5.38$ \\
\hline
\end{tabular}


Table 1 Proteins identified in membrane fraction using 2-DE coupled with MS/MS analysis (Continued)

\begin{tabular}{|c|c|c|c|c|c|c|c|c|c|}
\hline \multirow[t]{17}{*}{ Metabolism } & CaM-218* & Glutamine synthetase & 50 & 12963877 & 1 & -0.393 & 2 & $47.40 / 5.73$ & $50.72 / 5.32$ \\
\hline & CaM-308* & Fructose-bisphosphate aldolase $1^{k}$ & 182 & 399024 & 5 & -0.172 & 14 & $38.63 / 5.83$ & $39.99 / 5.62$ \\
\hline & CaM-310 & Fructose-bisphosphate aldolase (EC 4.1. 2.13) precursor $^{k}$ & 206 & 399024 & 6 & -0.172 & 17 & $38.74 / 5.83$ & $39.89 / 5.86$ \\
\hline & CaM-453* & Fructose-bisphosphate aldolase ${ }^{k}$ & 122 & 3913008 & 4 & -0.148 & 14 & $38.42 / 6.21$ & $37.10 / 6.70$ \\
\hline & $\mathrm{CaM}-322^{*}$ & Phosphoglycerate kinase precursor like & 124 & 82621134 & 5 & 0.128 & 11 & $50.35 / 8.19$ & $46.94 / 5.64$ \\
\hline & CaM-257 & Plastidic aldolase $\mathrm{k}^{\mathrm{k}}$ & 240 & 38096041 & 9 & -0.151 & 17 & $43.18 / 6.86$ & $35.52 / 5.61$ \\
\hline & $\mathrm{CaM}-210^{*}$ & Fructose-bisphosphate aldolase ${ }^{k}$ & 163 & 84468290 & 5 & -0.140 & 14 & $43.03 / 6.86$ & $40.35 / 5.35$ \\
\hline & CaM-460! & Glyceraldehyde 3-phosphate dehydrogenase' & 70 & 3413165 & 4 & 0.069 & 15 & $20.88 / 5.24$ & $41.91 / 6.66$ \\
\hline & CaM-216 & Glutamate-ammonia ligase (EC 6.3.1.2) delta precursor & 39 & 121344 & 1 & -0.390 & 2 & $47.65 / 6.18$ & $51.86 / 5.13$ \\
\hline & CaM-115! & Trypsin inhibitor, chain B (fragments) & 144 & 3318877 & 7 & -0.281 & 57 & $19.29 / 4.79$ & $14.86 / 5.07$ \\
\hline & CaM-214 & Glutamate-ammonia ligase (EC 6.3.1.2) delta precursor & 68 & 121344 & 1 & -0.390 & 2 & $47.65 / 6.18$ & $51.14 / 5.23$ \\
\hline & CaM-366* & Carbonic anhydrase $^{\mathrm{m}}$ & 55 & 20502881 & 2 & -0.159 & 4 & $35.28 / 6.96$ & $31.01 / 5.95$ \\
\hline & CaM-370* & Carbonic anhydrase $^{\mathrm{m}}$ & 67 & 20502881 & 2 & -0.159 & 5 & $35.28 / 6.96$ & $30.85 / 6.23$ \\
\hline & CaM-206! & Phosphoribulokinase & 71 & 1885326 & 6 & -0.289 & 7 & $39.23 / 5.41$ & $43.82 / 5.18$ \\
\hline & $\mathrm{CaM}-435^{*}$ & Carbonic anhydrase $^{\mathrm{m}}$ & 95 & 8954289 & 3 & -0.091 & 6 & $35.46 / 7.59$ & $29.73 / 6.47$ \\
\hline & $\mathrm{CaM}-438^{*}$ & Carbonic anhydrase $^{\mathrm{m}}$ & 56 & 8954289 & 2 & -0.091 & 4 & $35.46 / 7.59$ & $29.78 / 6.74$ \\
\hline & $\mathrm{CaM}-462^{*}$ & Glyceraldehyde-3-phosphate dehydrogenase A' & 200 & 120658 & 6 & -0.047 & 12 & $43.31 / 8.80$ & $44.49 / 6.81$ \\
\hline \multirow[t]{8}{*}{ Miscellaneous } & CaM-155! & Dynein-1-alpha heavy chain & 69 & 159490411 & 63 & -0.257 & 10 & $525.42 / 5.32$ & $61.98 / 5.11$ \\
\hline & CaM-54! & Activator of spomin & 65 & 145357734 & 8 & -0.634 & 24 & $17.25 / 9.63$ & $12.38 / 4.69$ \\
\hline & CaM-289 & Ribulose-1,5-biphosphate carboxylase/oxygenase large subunit & 129 & 10764577 & 5 & -0.254 & 10 & $51.58 / 5.96$ & $23.69 / 5.59$ \\
\hline & CaM-299! & Histone acetyltransferase GCN5 & 79 & 18410098 & 15 & -0.581 & 26 & $63.48 / 6.01$ & $30.69 / 5.63$ \\
\hline & CaM-38* & Ribulose bisphosphate carboxylase/Oxygenase large chain & 60 & 1750362 & 2 & -0.249 & 4 & $52.22 / 6.09$ & $56.17 / 4.30$ \\
\hline & $\mathrm{CaM}-138^{*}$ & Chromosome chr17 scaffold_16 & 149 & 225456471 & 4 & -0.342 & 4 & $33.35 / 5.67$ & $37.90 / 4.97$ \\
\hline & CaM-43* & Ribulose bisphosphate carboxylase large chain & 295 & 197294096 & 8 & -0.277 & 16 & $52.65 / 6.04$ & $64.35 / 4.29$ \\
\hline & CaM-290! & Intronic ORF, similar to LAGLIDADG endonuclease & 80 & 2943730 & 11 & -0.486 & 21 & 29.46/10.01 & $21.47 / 6.00$ \\
\hline
\end{tabular}


Table 1 Proteins identified in membrane fraction using 2-DE coupled with MS/MS analysis (Continued)

\begin{tabular}{|c|c|c|c|c|c|c|c|c|c|}
\hline \multirow[t]{9}{*}{ Unknown function } & CaM-443* & Predicted protein & 53 & 224119706 & 1 & 0.038 & 3 & $27.44 / 8.65$ & $31.20 / 6.64$ \\
\hline & CaM-263 & OSJNBb0085H11.1 protein & 50 & 38346013 & 1 & -.293 & 7 & $176.76 / 9.26$ & $53.68 / 5.61$ \\
\hline & CaM-478* & Putative uncharacterized protein & 64 & 147828109 & 19 & -0.788 & 0 & $58.79 / 6.46$ & $87.91 / 6.46$ \\
\hline & CaM-323* & Putative uncharacterized protein & 94 & 224284512 & 2 & -0.395 & 7 & $40.97 / 6.04$ & $44.21 / 5.66$ \\
\hline & CaM-477! & Unknown protein & 67 & 27497205 & 16 & -1.250 & 8 & $16.57 / 10.81$ & $65.11 / 6.62$ \\
\hline & CaM-171! & Unknown protein & 67 & 15236812 & 16 & -0.827 & 8 & $90.90 / 5.09$ & $74.93 / 5.11$ \\
\hline & CaM-64! & Hypothetical protein P0415D04.53 & 66 & 47496995 & 8 & -0.587 & 34 & $30.31 / 11.81$ & $24.12 / 4.77$ \\
\hline & CaM-267! & Hypothetical protein F26P21.180 & 67 & 3688187 & 10 & -0.645 & 22 & $57.25 / 7.64$ & $44.54 / 5.58$ \\
\hline & CaM-56! & Hypothetical protein OSJNBa0075N02.148 & 66 & 28972006 & 7 & -1.039 & 29 & $20.62 / 12.24$ & $22.37 / 4.49$ \\
\hline
\end{tabular}

${ }^{\mathrm{a}}$ Spot number as marked on the proteome (Figure 3B). The spot numbers are designated as CaM-X, where Ca indicates the organism (Cicer arietinum), M denotes the fraction (membrane), and X corresponds to the spot number. ${ }^{b}$ Protein identification number as in GenBank. ${ }^{C}$ NP represents the number of peptides. ${ }^{\mathrm{d}} \mathrm{GRAVY}$ value calculated using ProtParam tool available on ExPasy server. ${ }^{\overline{\mathrm{e}-m}}$ denotes the respective protein(s) identified from multiple spots. This could be caused by posttranslational modification(s) or different isoforms, protein degradation/synthesis. Spots marked by '*' were identified by Q-TRAP, ' $₫$ ' by QStar, and '!' by MALDI TOF-TOF analysis. 


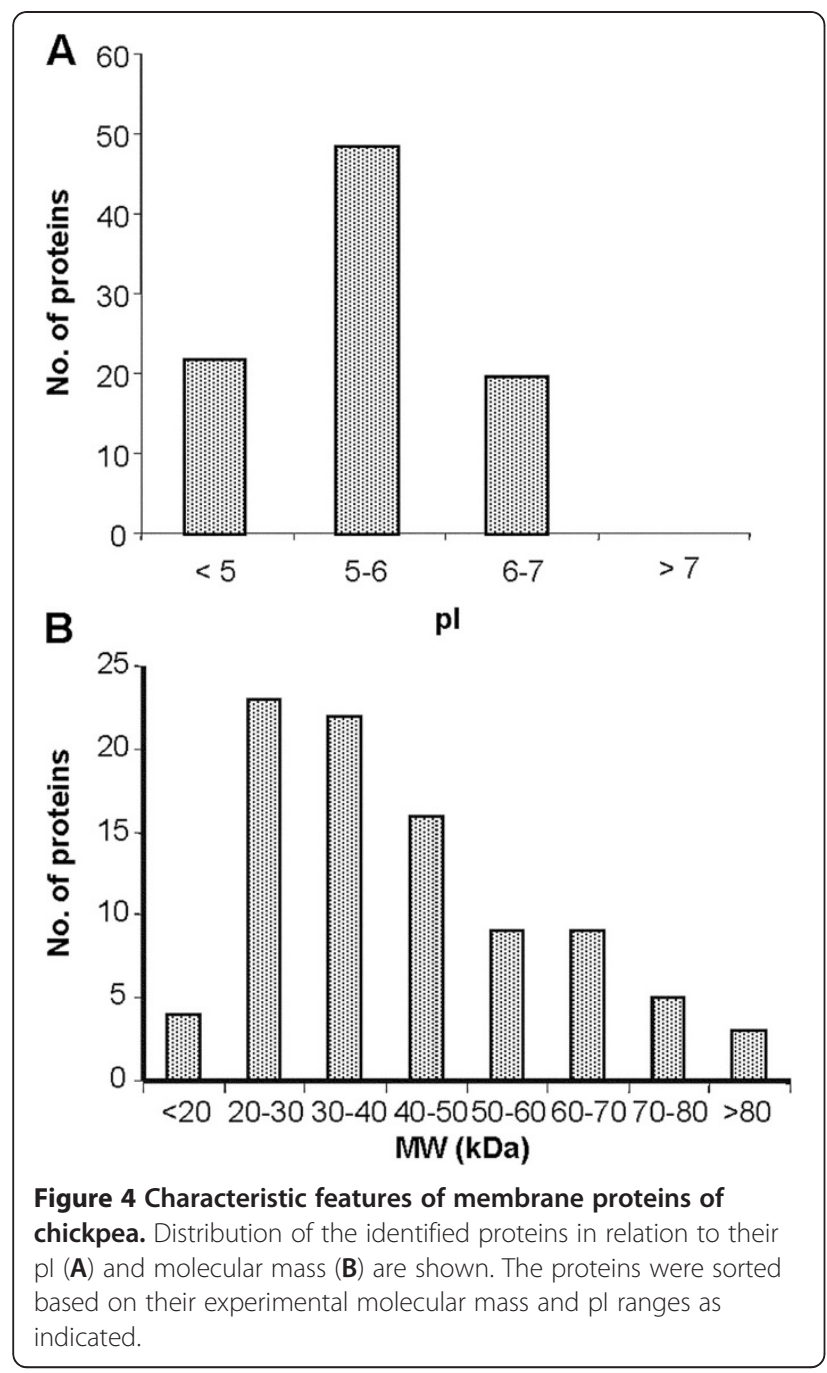

the identified proteins are designated as having putative TMDs, based upon TMpred analysis. It is notable that the number of integral membrane proteins identified in this study is significantly higher than those reported in previous gel-based membrane proteome analyses (Table 2).

Another valid indicator of the membrane association of proteins is their GRAVY value in the positive range, depicting their hydrophobic nature [23,24]. GRAVY value analysis was performed at the protein (Table 1) as well as peptide level (Additional file 4. Table S3). The

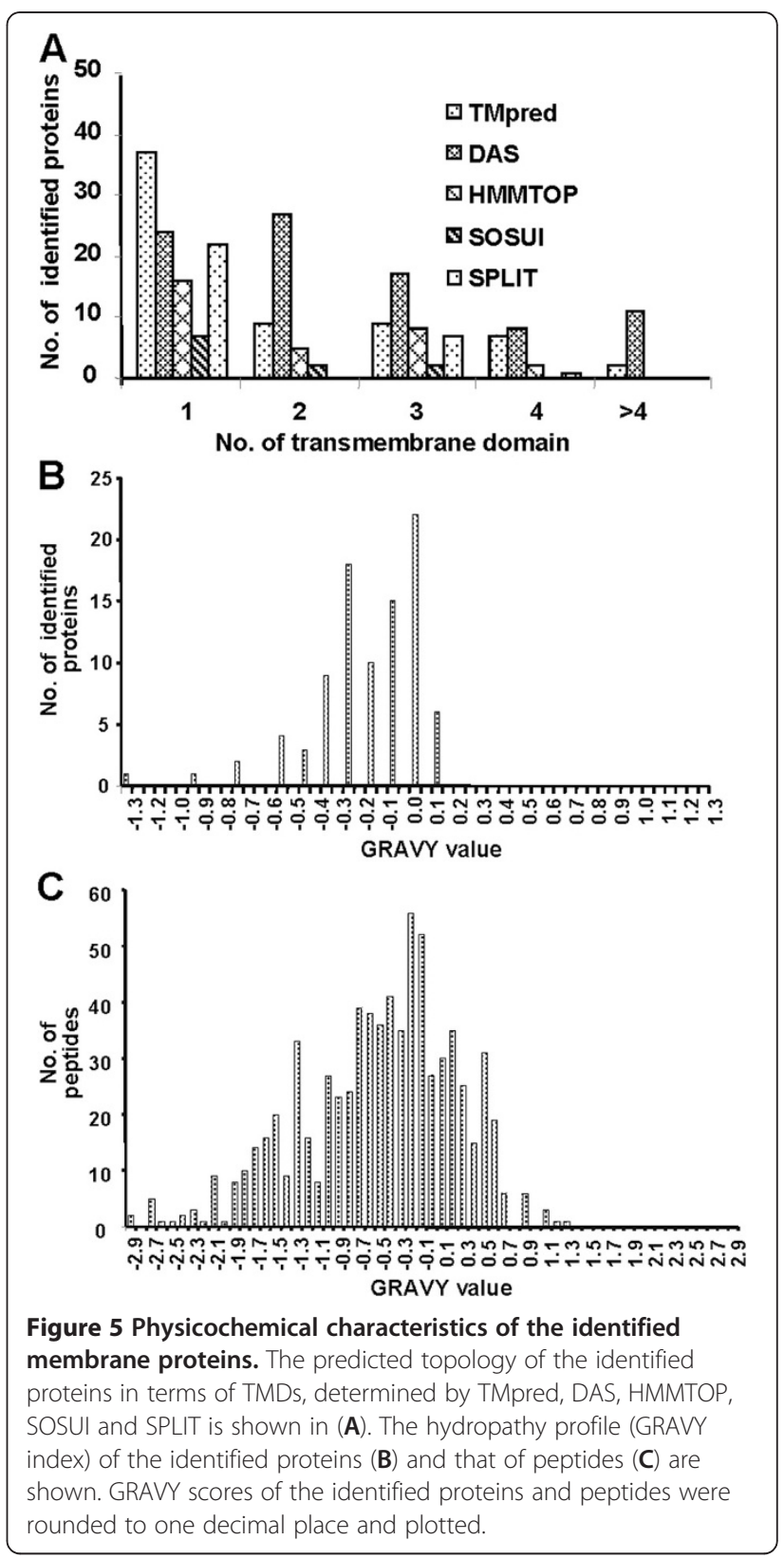

positive GRAVY value of the identified proteins ranged from 0.001 to 0.128 (Figure 5B), and that of the peptides from 0.014 to 1.287 (Figure 5C). While some proteins such as membrane protein $\mathrm{CH}$-like (CaM-247) with three putative TMDs showed negative GRAVY value $(-0.510)$, glyceraldehyde 3-phosphate dehydrogenase

Table 2 Integral membrane proteins identified in membrane proteomes

\begin{tabular}{lccc}
\hline \multicolumn{1}{c}{ Plant } & Total number of identified proteins & Integral proteins (having putative TMD $^{\text {a }}$ ) & \% of integral proteins identified \\
\hline Cicer arietinum & 91 & 64 & 70.3 \\
Medicago truncatulab $^{b}$ & 96 & 22 & 22.9 \\
Lupinus albus $^{c}$ & 37 & 18 & 48.6 \\
\hline
\end{tabular}

${ }^{\mathrm{a}}$ TMpred used as prediction tool. ${ }^{\mathrm{b}}$ Calculations adapted from TMpred analysis [6]. ${ }^{\mathrm{C}}$ Additional file 3 . Table S2 contains details of TMpred analysis as applied to the membrane proteome dataset of white lupin. 


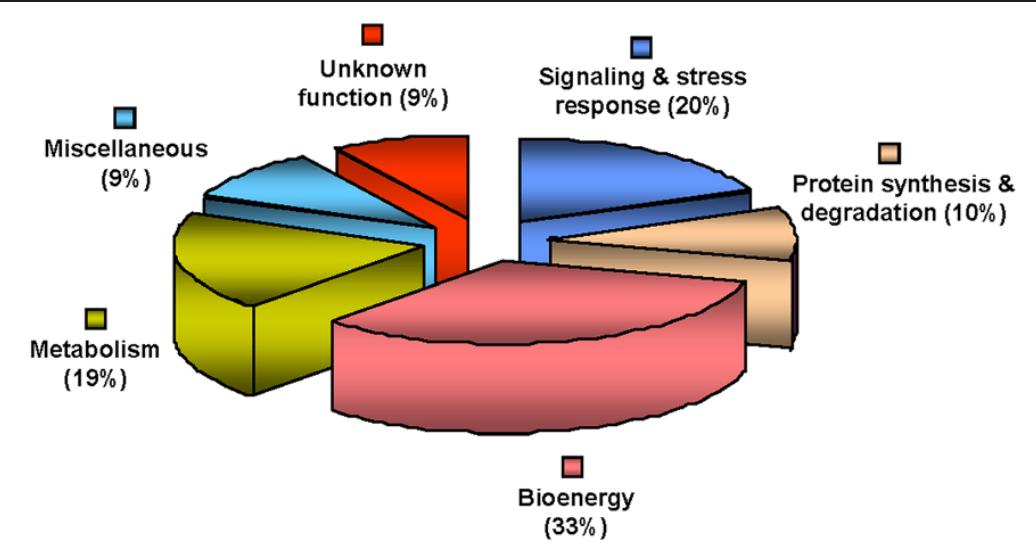

Figure 6 Functional classification of the membrane proteins of chickpea. The identified proteins were catalogued based upon their putative functions, assigned using protein function databases and literature search.

(GAPDH, CaM-460) with no predicted TMD scored positive GRAVY value (0.069). It has been reported that most of the integral cytoplasmic membrane proteins are hydrophobic, while the majority of integral outer membrane proteins are hydrophilic [4,24], causing the observed ambiguity in GRAVY values.

\section{Analysis of functional groups of membrane proteins}

The identified proteins were functionally classified into various categories (Figure 6) based on protein function database Pfam or InterPro and literature search. The assigned classes include bioenergy (33\%), signaling and stress response (20\%), metabolism (19\%), protein synthesis and degradation (10\%), miscellaneous (9\%) and proteins with unknown function (9\%). In a number of cases, the same protein was identified from multiple spots in the same gel. This suggests the possible posttranslational modification(s), which might lead to the change in isoelectric point and or molecular weight. For example, spots CaM-21 and 69 were identified as chlorophyll a/b-binding protein but they showed different pIs and molecular weights.

We identified many candidates that are known membrane residents, and also membrane-associated proteins. The most abundant class of proteins belonged to 'Bioenergy'. Members in this class are mainly associated with energy-production processes such as photosynthesis and oxidative phosphorylation. In green plants, chloroplast and mitochondria are the most prominent and abundant organelles. Most of the identified proteins in 'Bioenergy' belong to these organelles, such as the proteins involved in the formation of major complexes of photosynthetic apparatus such as light harvesting antenna complexes associated with PSI and PSII (CaM-21, 22, 69, 74 126, 127, and 184), cytochrome b6-f complex (CaM-242) and oxygen-evolving enhancer protein 1 and 2 (CaM-125 and 183). Protein spots CaM-319, 376 and 452 were identified as ferredoxin NADP reductase (FNR), which is tightly bound to the thylakoid membrane [25] and cause the reduction of $\mathrm{NADP}^{+}$during photosynthetic electron transport. Multiple subunits of ATP synthase such as alpha, beta and gamma were also identified.

The class 'Metabolism' contained proteins like glutamine synthetase (CaM-218) and glutamate ammonia ligase delta precursor (CaM-214 and 216), which are primarily involved in nitrogen metabolism. The protein spot CaM322 was identified as phosphoglycerate kinase (PGK), which has been found to be associated with the thylakoid membrane in higher plants [26]. Carbonic anhydrase, known to provide inorganic carbon for improved photosynthetic efficiency, was identified from multiple spots (CaM-366, 370, 435, and 438). Although carbonic anhydrase is primarily located in the chloroplast, it is also reported to be present in the microsomal and plasma membrane fractions [27]. It is increasingly apparent that many enzymes are not free in solution, but interact with membrane structures [28] or with other proteins [29]. The presence of metabolic pathway enzymes like aldolase as identified from multiple spots (CaM-210, 257, 308, 310, and 453), phosphofructokinase (CaM-206), and GAPDH (CaM-460 and 462), among others, highlights this phenomenon. It has been reported that aldolase interacts with V-ATPase [30], which may provide a basis for coupling glycolysis directly to the ATP-hydrolyzing proton pump [31]. In Arabidopsis, 5$10 \%$ of the cytosolic isoforms of each glycolytic enzyme is associated with the outer surface of mitochondria [32]. These glycolytic enzymes associated with mitochondria are catalytically competent and constitute a functional glycolytic pathway [33], though the significance of this micro-compartmentation of glycolysis has not been fully understood.

A subset of the identified proteins was presumably involved in 'Signaling and stress response'. This class 
included proteins such as calcineurin-like phosphoesterase (CaM-85) and membrane protein $\mathrm{CH} 1$-like (CaM247), the latter having putative SUN (Sad1/UNC-84) domain. Proteins having the SUN domain are involved in the formation of bridging structures, LINC (linker of nucleoskeleton and cytoskeleton) complex that plays an important role in DNA duplication, especially in the anchorage of centrosomes and spindle pole body to the nuclear envelope $[34,35]$. The discovery of SUN proteins in plant established the existence of LINC complex [36]. In animal, SUN proteins are known to involve in the transfer of mechanical force generated in cytosol to inner nuclear membrane [37], but such role in plants is unknown. Calcineurin-likephosphoesterase belongs to the protein family that includes diverse range of phosphoesterases, phosphoserine phosphatases, and nucleotidases. The exact role of this protein in signaling is not known; however, it is likely to be involved in phosphate mobilization either by cleavage of phosphate from phosphate-containing compounds or by metabolic changes [38]. The spots CaM-89 and 246 were identified as serine/threonine kinase. These kinases may act as receptor, which interact with other proteins to affect a wide array of processes, specifically in stress adaptation [39]. CaM-436 was identified as quinone oxidoreductase, a class of membrane enzymes that catalyse the oxidation or reduction of membrane-bound quinols/quinones. This protein has been reported to be associated with the plasma membrane [40] and microsomal membranes [41]. Protein spot CaM-326 was identified as cytochrome P450, one of the largest super families of enzymes. It uses electrons from $\mathrm{NAD}(\mathrm{P}) \mathrm{H}$ to catalyze activation of molecular oxygen, leading to regiospecific and stereospecific oxidative attack of a plethora of substrates $[42,43]$. Plant P450s are a class of proteins anchored on the cytoplasmic side to ER [44], but is also found in inner mitochondrial membranes [45] as well as in tonoplasts [46].

In this class, another interesting candidate (CaM-89) is the one encoded by COK-4 gene that confers resistance to anthracnose caused by the fungal pathogen Colletotrichum. In addition to displaying high similarity to the Pto kinase, one of the best characterized $R$ gene products, the predicted COK-4 protein contains a highly hydrophobic membrane-spanning region [47]. CaM-432 was also depicted to be a disease resistance protein containing LRR repeat. CaM-483 was identified as BiP, the ER-resident molecular chaperone involved in ER stress signaling. In plants, BiP plays a key role in attenuating ER stress and suppresses the activation of the unfolded protein response [48]. We also identified HSPs such as chaperone DnaK (CaM-99), chaperonin-60 (CaM-94, 150, and 421), and GloEL protein (CaM-157), which prevent protein misfolding and random aggregation inside the cell. The major HSP families are necessary for the assembly and unfolding or transport of proteins through membranes $[49,50]$.

The class 'Protein synthesis and degradation' predominantly include ribosomal proteins (CaM-39, 208, 240, 208, 209 and 283), putative glutamate tRNA ligase (CaM-223), proteasome subunit alpha type (CaM-301), polyubiquitin (CaM-249), and mitochondrial processing peptidase beta subunit (CaM-407). It has been reported that polysomes are linked to actin filaments, which in turn are associated with the plasma membrane [51]. Furthermore, ribosomes are also attached to the ER and nuclear membrane through the larger subunit. The most common pathway for degradation of cellular proteins is the ubiquitin proteasome pathway. We could identify proteins associated with these pathways such as polyubiquitin (CaM-249) and proteasome subunit alpha type (CaM-301). Ubiquitin is known to be the most conserved protein required for ATP-dependent protein degradation and involved in protein transport. These proteins were identified from the tonoplast [30], as well as from the plasma membrane [52].

The 'Miscellaneous' class accounted for 9\% of the proteins identified. This class include activator of spomin (CaM-54), dynein-1-alpha heavy chain (CaM-155), chromosome chr17 scaffold_16 (CaM-138), and histone acetyltransferase (HAT, CaM-299), among others. HAT

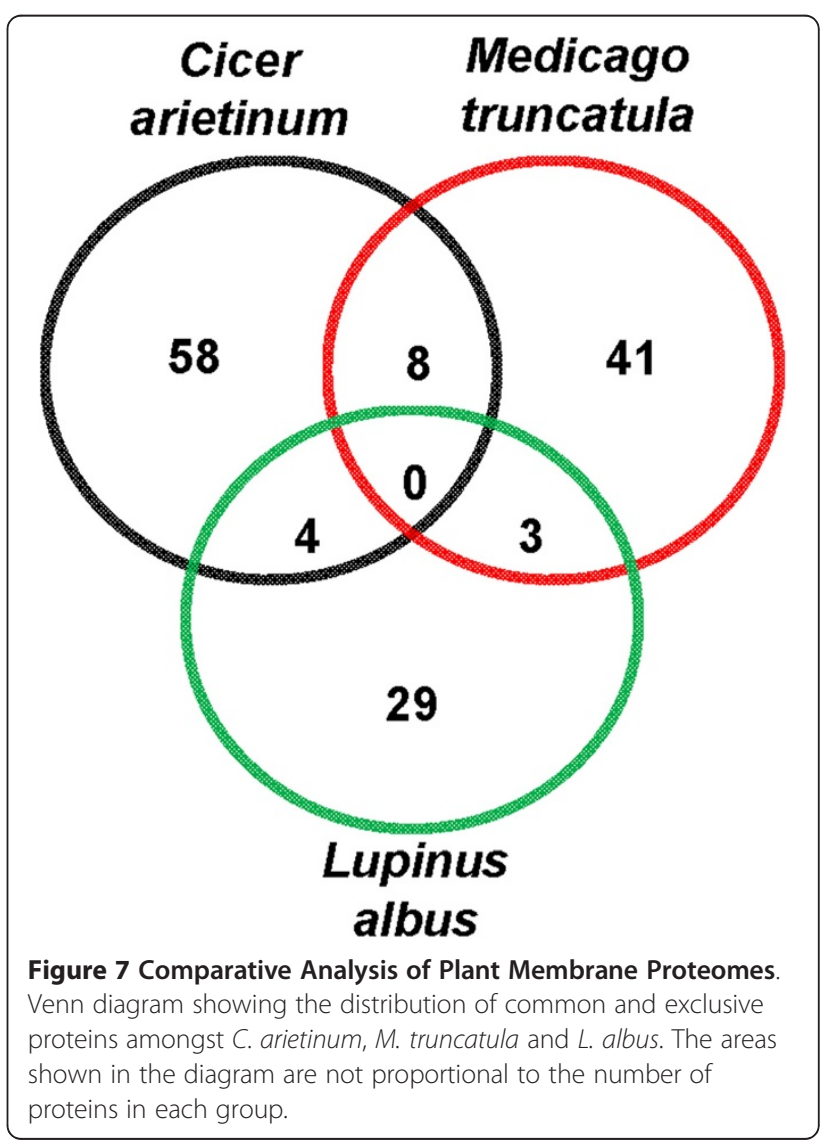


has been linked to transcriptional activation of various genes and is known to associate with mammalian inner nuclear membrane [53]. The activator of spomin is known to involve in the activation of a subset of sugarresponsive genes and control the carbon flow in plants [54]. Chromosome chr17 scaffold_16 encodes for ATPdependent Clp protease ATP-binding subunit. Clp proteases are known to degrade both soluble and membrane-bound substrates [55] and are reported to be associated with the stroma as well as the inner envelope membrane in plants [56]. The proteome map revealed 9\% proteins as hypothetical or proteins with unknown function, which were subjected to domain analysis using InterProScan. The analysis led to the identification of different conserved domains, thereby providing valuable insight into their functional implications (Additional file 5. Table S4). The putative conserved domain was bacterial transferase hexapeptide repeat in CaM-443, kinesin-related domain in CaM-56, and ATPase, AAA type core in CaM-323, among others. Intriguingly, membrane receptors, aquaporins, and transporters could not be identified, possibly due to their low abundance and complex physicochemical properties. Nevertheless, the distribution of various functional classes bear resemblance to previously reported membrane proteome datasets of rice [7].

\section{Comparative analysis of membrane proteomes}

To investigate the comparative proteomics of membrane proteins at organismal level, the representative membrane proteomes of Medicago truncatula [20] and Lupinus albus [21] were compared with that of chickpea. For the purpose, we considered only gel-based proteomes of the microsomal fraction. Very few proteins were found to be common between any two datasets and interestingly, none of the proteins was found to be common amongst all the datasets (Figure 7, Additional file 6. Table S5). The percentage of proteins found to be exclusive to each proteome varied as $83 \%$ in chickpea, $79 \%$ in Medicago and $80 \%$ in white lupin. Given the comparison between the proteome of any two species, chickpea showed higher percentage of similarity with Medicago. The poor overlap amongst the proteome datasets can be attributed to the fact that the representative proteomes are unsaturated and more so, the microsomal fraction of chickpea was extracted from aerial tissues as against root tissues used for Medicago and white lupin.

\section{Conclusions}

Most plant membrane proteomes till date have been developed from roots, the notable exceptions being leaves [57], trichomes [58], seedlings [59], and aerial tissues (this study). Unlike root tissues that arise from root apical meristems, the aerial tissues are initiated by the shoot apical meristems, which show more diversity. In recent years, shoot meristems have received considerable attention in view of their importance in plant development and stress adaptation [60]. Further, only a small fraction of integral membrane proteins have been confirmed experimentally, and most of them came from in silico analyses of genome datasets of the model plants. The difficulties associated with the study of membrane proteins in non-model plants has been demonstrated in a recent proteomic study [61]. This underscores the importance of the study of membrane proteins in chickpea, whose genome is yet to be sequenced. This study provides a firm indication of a number of membraneassociated proteins to which function is yet to be assigned. The proteome revealed many key membraneassociated proteins, for example, serine threonine kinase homolog COK4, calcineurine-like phosphoesterase, activator of spomin, and chromosome chr17 scaffold_16, among others, which were not reported earlier.

\section{Methods}

\section{Plant materials and growth condition}

Chickpea (Cicer arietinum L.) seeds were soaked in water, kept overnight in dark and grown in pots (10 seedlings $/ 1.5 \mathrm{~L}$ capacity pots with $18 \mathrm{~cm}$ diameter) containing a mixture of soil and soilrite $(2: 1, w / w)$. The seedlings were maintained at $25 \pm 2{ }^{\circ} \mathrm{C}, 50 \pm 5 \%$ relative humidity under $16 \mathrm{~h}$ photoperiod $\left(270 \mu \mathrm{mol} \mathrm{m}^{-2} \mathrm{~s}^{-1}\right.$ light intensity) as described previously [17]. The pots were provided with $100 \mathrm{ml}$ of water every day that maintained the soil moisture content to approx. 30\%. The aerial parts (stem and leaves) of 3-week-old seedlings were sampled as experimental materials.

\section{Isolation of membrane fraction}

The membrane i.e., microsomal fraction was isolated as described earlier [62] with few modifications. Approximately, $10 \mathrm{~g}$ tissue was ground into powder in liquid nitrogen with $1 \%(\mathrm{w} / \mathrm{w})$ polyvinylpolypyrroledone (PVPP). The tissue powder was homogenized in homogenizing buffer [0.25 mM sucrose, $3 \mathrm{mM}$ EDTA, $5 \mathrm{mM}$ DTT, $10 \mathrm{mM}$ ascorbic acid, $70 \mathrm{mM}$ Tris-MES (pH 8.0), $0.25 \mathrm{mM}$ PMSF and protease inhibitor cocktail (Sigma)] using a homogenizer (PRO Scientific, USA). The cell debris was removed from the homogenate by filtration through four-layered cheese cloth and the filtrate was centrifuged at $6000 \times g$ for $10 \mathrm{~min}$ at $4^{\circ} \mathrm{C}$. The supernatant was recovered and centrifuged at $150000 \times g$ for $45 \mathrm{~min}$ at $4^{\circ} \mathrm{C}$. The resulting pellet containing the membrane fraction was suspended in suspension buffer (1.1 mM glycerol, $5 \mathrm{mM}$ DTT, and $10 \mathrm{mM}$ Tris-MES, $\mathrm{pH}$ 8.0). 


\section{Marker enzyme assays}

The presence of different subcellular membranes was determined by assaying activity their respective marker enzymes. The activities of orthovanadate-, azide-, nitrate-sensitive ATPase and latent IDPase were measured for plasma membrane, mitochondrial membrane, tonoplast and Golgi membrane, respectively [63,64]. In brief, $30 \mu \mathrm{g}$ membrane proteins were suspended in $30 \mathrm{mM}$ Tris-MES [pH 6.5 (vanadate-sensitive ATPase), pH 8.0 (nitrate and azide-sensitive ATPase), and pH 7.5 (latent IDPase)]. The reactions were performed in $1 \mathrm{ml}$ solution containing $3 \mathrm{mM} \mathrm{MgSO} 4,0.1 \mathrm{mM}$ sodium molybdate, $50 \mathrm{mM} \mathrm{KCl}$ and $3 \mathrm{mM} \mathrm{ATP}$, with or without ATPase inhibitor $\left(100 \mu \mathrm{M} \mathrm{Na} \mathrm{VO}_{4}, 50 \mathrm{mM} \mathrm{KNO}\right.$, and $1 \mathrm{mM} \mathrm{NaN}_{3}$ ) at $38^{\circ} \mathrm{C}$ to minimise the hydrolysis of ATP. To subtract the residual $\mathrm{Pi}$ in isolated fraction, the reactions were also performed without addition of ATP. The released Pi was determined as described previously [65]. The reaction was stopped by the addition of $1 \mathrm{ml}$ Ames's colour reagent $[1$ part ascorbic acid (10\%) and 6 parts ammonium molybdate $\left(0.42 \%\right.$ in $\left.1 \mathrm{~N} \mathrm{H}_{2} \mathrm{SO}_{4}\right)$ ] containing $0.1 \%(\mathrm{w} / \mathrm{v})$ SDS. The colour was allowed to develop for $20 \mathrm{~min}$. After termination with $10 \%(\mathrm{w} / \mathrm{v})$ sodium citrate, the absorbance was measured at $820 \mathrm{~nm}$. For latent IDPase, the reaction was carried out with $3 \mathrm{mM}$ IDP-salt, either in presence or absence of $0.1 \mathrm{mM}$ sodium molybdate. The activity was determined on freshly isolated membrane fraction then after 5 days of incubation at $4^{\circ} \mathrm{C}$.

\section{Extraction and quantification of membrane proteins}

Membrane proteins were extracted using the organic solvent mixture of chloroform/methanol as described previously [66]. The microsomal fraction was suspended in $1 \mathrm{ml}$ of suspension buffer and divided in 10 subfractions of $0.1 \mathrm{ml}$. The aliquots were slowly added to $0.9 \mathrm{ml}$ of cold chloroform/methanol mixtures (0:9 to 9:0, $\mathrm{v} / \mathrm{v}$ ) and kept on ice for $15 \mathrm{~min}$. Intermittent vortexing of samples was carried out during the incubation. The mixtures were centrifuged at $12000 \times \mathrm{g}$ for $20 \mathrm{~min}$ at $4^{\circ} \mathrm{C}$. The pellet fractions containing insoluble proteins were retrieved carefully and to the respective supernatants, 2-5 volumes of chilled acetone was added, followed by incubation at $-20^{\circ} \mathrm{C}$ and the precipitated proteins collected by centrifugation. The soluble and insoluble fractions' membrane proteins were resuspended in the buffer containing $7 \mathrm{M}$ urea, $2 \mathrm{M}$ thiourea, and $4 \%$ CHAPS $(\mathrm{w} / \mathrm{v})$. The protein concentration was determined using the 2-D Quant kit (GE Healthcare).

\section{Measurement of phytopigments}

The spectrophotometric assay was used to determine the content of phytopigments such as chlorophylls and carotenoids. After removal of insoluble proteins, equal volume of organic phase of each ratio of chloroform/ methanol was added to $80 \%$ chilled acetone. Mixtures were centrifuged at $2700 \times \mathrm{g}$ for $10 \mathrm{~min}$ and the supernatant was taken to measure the absorbance at 663, 645 and $470 \mathrm{~nm}$, respectively [67]. The amounts of phytopigments were calculated as follows:

$$
\begin{aligned}
\text { Chl a } & =\left[\left(12.7 \times \mathrm{A}_{663}\right)-\left(2.69 \times \mathrm{A}_{645}\right)\right], \text { Chl b } \\
& =\left[\left(22.9 \times \mathrm{A}_{645}\right)-\left(4.68 \times \mathrm{A}_{663}\right)\right] \text { and carotenoids } \\
& =\left[\left(1000 \times \mathrm{A}_{470}\right)-(3.27 \times \text { Chla }+1.04 \times \text { Chlb })\right] / 227
\end{aligned}
$$

\section{2-DE of membrane proteins and data analysis}

Since the organic solvent extraction at $6: 3$ ratio of chloroform/methanol was found to be optimal for membrane proteins, isoelectric focusing (IEF) was carried out with $100 \mu \mathrm{g}$ of proteins from the pellet fraction. The immobilized gel strips (13 cm, pH $3-10$ or $4-7$, GE Healthcare) were rehydrated overnight in $250 \mu \mathrm{l}$ of rehydration buffer $[7 \mathrm{M}$ urea, $2 \mathrm{M}$ thiourea, 4\% (w/v) CHAPS, $60 \mathrm{mM}$ DTT, 2\% (v/v) pharmalyte (pH 3-10 or 4-7), and $0.05 \%(\mathrm{w} / \mathrm{v})$ bromophenol blue]. During cuploading, proteins were diluted with rehydration buffer to final concentration of $1 \mu \mathrm{g} / \mu \mathrm{l}$ and loaded either at anodic or cathodic ends. Initially, proteins were electrofocused at lower voltage and later with higher voltage up to $85000 \mathrm{VhT}$ at $20^{\circ} \mathrm{C}$ using IPGphor system (GE Healthcare). After IEF, the strips were subjected to reduction with $1 \%(\mathrm{w} / \mathrm{v})$ DTT in $10 \mathrm{ml}$ of equilibration buffer [6 M urea, $50 \mathrm{mM}$ Tris- $\mathrm{HCl}(\mathrm{pH} 8.8), 30 \%$ (v/v) glycerol and $2 \%(\mathrm{w} / \mathrm{v}) \mathrm{SDS}$, followed by alkylation with $2.5 \%(\mathrm{w} / \mathrm{v})$ iodoacetamide in the same buffer. The strips were then loaded on top of $12.5 \%$ polyacrylamide gels for SDS-PAGE. The electrophoresed proteins were stained with silver stain plus kit (Bio-Rad). The silver stained gels were scanned with Bio-Rad FluorS equipped with a 12-bit camera. The 2-DE gels were analyzed with PDQuest version 7.2.0 (Bio-Rad). Three replicate 2-DE gels, corresponding to at least two biological replicates were matched together to generate a composite image conventionally known as first level matchset. Protein spots present in at least two of the three gels were considered for analysis. Experimental molecular mass and pI for each protein were determined from 2-DE image using standard molecular mass protein marker (Bio-Rad).

\section{Protein identification using MALDI-TOF/TOF and LC-ESI-MS/MS}

The protein spots were excised manually, washed twice with deionized water, and trypsin in-gel digestion was performed [17]. The peptide extract was vacuum dried. While reconstitution of the peptides for MALDI-TOF/ TOF was performed in $3 \mu \mathrm{l}$ of $50 \%$ (v/v) $\mathrm{ACN}$ and $0.1 \%$ $(\mathrm{v} / \mathrm{v})$ TFA, the same was performed in $7 \mu \mathrm{l}$ of $50 \%(\mathrm{v} / \mathrm{v})$ 
$\mathrm{ACN}$ and $0.1 \%(\mathrm{v} / \mathrm{v}) \mathrm{HCOOH}$ for LC-MS/MS. Instruments used for analysis were 4800 MALDI TOF/TOF Analyzer (Applied Biosystems), QStar Elite coupled to Tempo nano MDLC (Applied Biosystems) equipped with ion spray source running Analyst QS software, and ultimate 3000 nano HPLC system (Dionex) coupled to a 4000 QTRAP mass spectrometer (Applied Biosystems).

The acquired mass spectra were searched using Mascot search engine (www.matrixscience.com). The following parameters were used: maximum allowed missed cleavage 1, fixed amino acid modification as carbamidomethyl and variable amino acid modifications either oxidation (M) or acetyl (N-term) or both, taxonomy set to Viridiplantae/Oryza/Arabidopsis, and databases used MSDB or Ludwig NR. The peptide and fragment mass tolerance for spectra obtained from MALDI and QStar were $100 \mathrm{ppm}, 0.3 \mathrm{Da}$, and $100 \mathrm{ppm}, 0.4 \mathrm{Da}$, respectively, while for TRAP it was 1.2 and $0.6 \mathrm{Da}$. Only those protein samples whose MOWSE score $[68,69]$ was above the significant threshold level $(\mathrm{p}<0.05)$ as determined by MASCOT were considered. Since chickpea genome is not sequenced, therefore a homology based search was performed. The details regarding the precursor ion mass, expected molecular weight, theoretical molecular weight, delta, score, rank, charge, number of missed cleavages, peptide sequence, database, taxonomy, and spectra for proteins identified with a single peptide are given in in Additional file 7. A list of each peptide score and threshold score of identified proteins is given in Additional file 8 .

\section{Bioinformatic analysis}

The prediction of transmembrane domain (TMD) of the identified proteins were carried out using TMpred (http://www.ch.embnet.org/software/TMPRED_form.html), DAS (http://www.sbc.su.se/ miklos/DAS/), HMMTOP (http://www.enzim.hu/hmmtop/), Sosui (http://bp.nuap. nagoya-u.ac.jp/sosui/sosui_submit.html) and SPLIT (http:// split.pmfst.hr/ split/4/). Grand Average of Hydropathicity (GRAVY) value for each protein and peptide was calculated using ProtParam tool available at the Expasy server (http://au.expasy.org/tools/protparam.html). To determine the function of unknown proteins, domain analysis was performed to predict the conserved domain using the InterPro (http://www.ebi.ac.uk/interpro/) database and queried for domains in the SMART (http://smart. embl-heidelberg.de/), Panther (http://www.Pantherdb.org/), and Pfam (http://www.sanger.ac.uk/software/Pfam/) databases.

\section{Additional files}

Additional file 1: Figure S1. 2-DE gel profile of chickpea membrane proteins using different sample loading methods and variable range IPG strips.
Additional file 2: Table S1. Prediction of TMDs in the identified proteins using five different programs.

Additional file 3: Table S2. Prediction of TMDs (based upon TMpred) in the membrane proteome dataset of Lupinus albus.

Additional file 4: Table S3. Calculation of GRAVY value of each peptide identified by MS/MS analysis.

Additional file 5: Table S4. Domain analysis of proteins of unknown function.

Additional file 6: Table S5. Comparative analysis of membrane proteome datasets of different plants.

Additional file 7: Details of mass spectra of proteins identified with single peptide.

Additional file 8: Details of each peptide score and threshold score of identified proteins.

\section{Abbreviations}

2-DE: Two-Dimensional gel Electrophoresis; DTT: Dithiothreitol; GRAVY: Grand Average of hydropathicity; IDPase: Inosine Diphosphatase; IEF: IsoElectric Focusing; TMD: TransMembrane Domain; SDS: Sodium Dodecyl Sulphate; PAGE: Polyacrylamide Gel Electrophoresis.

\section{Competing interests}

The authors declare that they have no competing interests.

\section{Author's contributions}

$D K J, A D, S C$ and NC designed the study, DKJ, PS, and DR carried out the experiments, PM and SG performed the bioinformatic analysis, DKJ, DR, SC and NC wrote the manuscript. All authors read and approved the final manuscript.

\section{Acknowledgments}

This work was supported by the Department of Biotechnology (DBT) [BT/PR/ 10677/PBD/16/795] and the Council of Scientific and Industrial Research (CSIR) [38(1255)11/EMR-II], Govt. of India. Support of the DBT pre-doctoral fellowships to D.K.J. and P.M. and post-doctoral fellowship to D.R. is also acknowledged. The authors thank the CSIR for providing pre-doctoral fellowships to P.S. and S.G. No conflict of interest declared. The authors thank Mr. Jasbeer Singh for illustrations and graphical representations in the manuscript.

Received: 26 April 2012 Accepted: 25 September 2012

Published: 2 October 2012

\section{References}

1. Schwacke R, Flugge UI, Kunze R: Plant membrane proteome database. Plant Physiol Biochem 2004, 42:1023-1034.

2. Wu CC, Yates JR: The application of mass spectrometry to membrane proteomics. Nature Biotechnol 2003, 21:262-267.

3. Groen AJ, Lilley KS: Proteomics of total membranes and subcellular membranes. Expert Rev Proteomics 2010, 7:867-878.

4. Santoni $V$, Molloy $M$, Rabilloud $T$ : Membrane proteins and proteomics: un amour impossible? Electrophoresis 2000, 21:1054-1070.

5. Ephritikhine G, Ferro M, Rolland N: Plant membrane proteomics. Plant Physiol Biochem 2004, 42:943-962.

6. Rolland N, Ferro M, Ephritikhine G, Marmagne A, Ramus C, Brugière S, Salvi D, Seigneurin-Berny D, Bourguignon J, Barbier-Brygoo H, Joyard J, Garin J: A versatile method for deciphering plant membrane proteomes. J Exp Bot 2006, 57:1579-1589.

7. Komatsu S, Konishi H, Hashimoto M: The proteomics of plant cell membranes. J Exp Bot 2007, 58:103-112.

8. Kota U, Goshe MB: Advances in qualitative and quantitative plant membrane proteomics. Phytochemistry 2011, 72:1040-1060.

9. Baker DG, Bianchi S, Blondon F, Dattee Y, Duc G, Flament P, Gallusci P, Genier G, Guy P, Muel X, Tourneur J, Denarie J, Huguet T: Medicago trancatula, a model plant for studying the molecular genetics of the Rhizobium-legume symbiosis. Plant Mol Biol Rep 1990, 8:40-49. 
10. Singh KB, Ocampo B, Robertson LD: Diversity for abiotic and biotic stress resistance in the wild annual Cicer species. Genet Res Crop Evo 1998, 45:9-17

11. Winter P, Benko-Iseppon AM, Huttel B, Ratnaparkhe M, Tullu A, Sonnante G, Pfaff T, Tekeoglu M, Santra D, Sant VJ, Rajesh PN, Kahl G, Muehlbauer FJ: A linkage map of the chickpea (Cicer arietinum $\mathrm{L}$ ) genome based on recombinant inbred lines from a $C$ arietinum $\times$ C reticulatum cross: localisation of resistance genes for Fusarium wilt races 4 and 5 . Theor Appl Genet 2000, 101:1155-1163.

12. Molina C, Rotter B, Horres R, Udupa SM, Bessre B, Bellarmino L, Baum M, Matsumura H, Terauchi R, Khal G, Winter P: SuperSAGE: the drought stressresponsive transcriptome of chickpea roots. BMC Genomics 2008, 9:553.

13. Ashraf N, Ghai D, Barman P, Basu S, Gangisetty N, Mandal MK, Chakraborty N, Datta A, Chakraborty S: Comparative analysis of genotype dependent expressed sequence tags and stress-responsive transcriptome of chickpea wilt illustrate predicted and unexpected genes and novel regulators of plant immunity. BMC Genomics 2009, 10:415.

14. Flowers TJ, Gaur PM, Gowda CL, Krishnamurthy L, Samineni S, Siddique KH, Turner NC, Vadez V: Salt sensitivity in chickpea. Plant Cell Environ 2009, 33:490-509.

15. Varshney RK, Hiremath PJ, Lekha P, Kashiwagi J, Balaji J, Deokar AA, Vadez V, Xiao Y, Srinivasan R, Gaur PM, Siddique KH, Town CD, Hoisington DA: A comprehensive resource of drought- and salinity-responsive ESTs for gene discovery and marker development in chickpea (Cicer arietinum L). BMC Genomics 2009, 10:523.

16. Garg R, Patel RK, Jhanwar S, Priya P, Bhattacharjee A, Yadav G, Bhatia S, Chattopadhyay D, Tyagi AK, Jain M: Gene discovery and tissue-specific transcriptome analysis in chickpea with massively parallel pyrosequencing and web resource development. Plant Physiol 2011, 156:1661-1678.

17. Bhushan D, Pandey A, Chattopadhyay A, Choudhary MK, Chakraborty S, Datta A, Chakraborty N: Extracellular matrix proteome of chickpea (Cicer arietinum $\mathrm{L}$ ) illustrates pathway abundance, novel protein functions and evolutionary perspect. J Proteome Res 2006, 5:1711-1720.

18. Pandey A, Choudhary MK, Bhushan D, Chattopadhyay A, Chakraborty S, Datta A, Chakraborty N: The nuclear proteome of chickpea (Cicer arietinum $\mathrm{L}$ ) reveals predicted and unexpected proteins. J Proteome Res 2006, 5:3301-3311.

19. Tan S, Tan HT, Chung MC: Membrane proteins and membrane proteomics. Proteomics 2008, 8:3924-3932.

20. Valot B, Gianinazzi S, Eliane DG: Sub-cellular proteomic analysis of a Medicago trancatula root microsomal fraction. Phytochemistry 2004, 65:1721-1732

21. Tian L, Peel GJ, Lei Z, Aziz N, Dai X, He J, Watson B, Zhao PX, Sumner LW, Dixon RA: Transcript and proteomic analysis of developing white lupin Lupinus albus L roots. BMC Plant Biol 2009, 9:1

22. Schwacke R, Schneider A, Van der Graaff E, Fischer K, Catoni E, Desimone M, Frommer WB, Flugge U, Kunze R: ARAMEMNON, a novel database for Arabidopsis integral membrane proteins. Plant Physiol 2003, 131:16-26.

23. Molloy MP: Two-dimensional electrophoresis of membrane proteins using immobilized pH gradients. Anal Biochem 2000, 280:1-10.

24. Nouwens AS, Cordwell SJ, Larsen MR, Molloy MP, Gillings M, Willcox MDP, Walsh BJ: Complementing genomics with proteomics: the membrane subproteome of Pseudomonas aeruginosa PAO1. Electrophoresis 2000, 21:3797-3809.

25. Schneeman R, Krogmann DW: Polycation interactions with spinach ferredoxin-nicotinamide adenine dinucleotide phosphate reductase. J Biol Chem 1975, 250:4965-4971.

26. Suss KH, Arkona C, Manteuffel R, Adler K: Calvin cycle multienzyme complexes are bound to chloroplast thylakoid membranes of higher plants in situ. Proc Natl Acad Sci USA 1993, 90:5514-5518.

27. Utsunomiya $\mathrm{E}_{1}$ Muto $\mathrm{S}$ : Carbonic anhydrase in the plasma membranes from leaves of $C_{3}$ and $C_{4}$ plants. Physiol Plantarum 1993, 88:413-419.

28. Martin SW, Glover BJ, Davies JM: Lipid microdomains-plant membranes get organized. Trends Plant Sci 2005, 10:263-265.

29. Uhrig JF: Protein interaction networks in plants. Planta 2006, 224:771-781.

30. Konishi H, Maeshima M, Komatsu S: Characterization of vacuolar membrane proteins changed in rice root treated with gibberellin. J Proteome Res 2005, 4:1775-1780.

31. Lu M, Holliday LS, Zhang L, Dunn WA Jr, Gluck SL: Interaction between aldolase and vacuolar $\mathrm{H}^{+}$-ATPase: evidence for direct coupling of glycolysis to the ATP-hydrolyzing proton pump. J Biol Chem 2001, 276:30407-30413.

32. Mustroph A, Sonnewald U, Biemelt S: Characterisation of the ATPdependent phosphofructokinase gene family from Arabidopsis thaliana. FEBS Lett 2007, 7581:2401-2410.

33. Giege $P$, Heazlewood IL, Roessner-Tunali U, Millar AH, Fernie AR, Leaver CJ Sweetlove $\sqcup$ : Enzymes of glycolysis are functionally associated with the mitochondrion in Arabidopsis cells. Plant Cell 2003, 15:2140-2151.

34. Kemp CA, Song MH, Addepalli MK, Hunter G, Connell KO: Suppressors of zyg-1 define regulators of centrosome duplication and nuclear association in Caenorhabditis elegans. Genetics 2007, 176:95-113.

35. Starr DA: A nuclear envelope bridge positions nuclei and moves chromosomes. J Cell Sci 2009, 122:577-586.

36. Graumann K, Runions J, Evans DE: Characterization of SUN-domain proteins at the higher plant nuclear envelope. Plant J 2009, 61:134-144.

37. Wang N, Tytell JD, Ingber DE: Mechanotransduction at a distance: mechanically coupling the extracellular matrix with the nucleus. Nat Rev Mol Cell Biol 2009, 10:75-82.

38. Muller R, Morant M, Jarmer H, Nilsson L, Nielsen TH: Genome-wide analysis of the Arabidopsis leaf transcriptome reveals interaction of phosphate and sugar metabolism. Plant Physiol 2007, 143:156-171.

39. Afzal AJ, Wood AJ, Lightfoot DA: Plant receptor-like serine threonine kinases: roles in signaling and plant defense. Mol Plant-Microbe Interact 2008, 21:507-517.

40. Trost $P$, Foscarini S, Preger V, Bonora P, Vitale L, Pupillo P: Dissecting the diphenylene idonium-sensitive NADPH: quinone oxidoreductase of zucchini plasma membrane. Plant Physiol 1997, 114:737-746.

41. Pupillo P, Valenti V, De Luca L, Hertel R: Kinetic characterization of reduced pyridine nucleotide dehydrogenase (duroquinone-dependent) in Cucurbita mirosomes. Plant Physiol 1986, 80:384-389.

42. Wreck-reichhart D, Feyereisen R: Cytochrome P450: a success story. Genome Biol 2000, 6:30031-30039.

43. Isin EM, Guengerich FP: Complex reactions catalyzed by cytochrome P450 enzymes. Biochim Biophys Acta 2007, 1770:314-329.

44. Bak S, Beisson F, Bishop G, Hamberger B, Höfer R, Paquette S, Werck-Reichhart D: Cytochromes P450. In The Arabidopsis Book Number 9. Rockville, MD: American Society of Plant Biologists; 2011.

45. Tijet $N$, Helvig C, Feyereisen R: The cytochrome P450 gene superfamily in Drosophila melanogaster: annotation, intron-exon organization and phylogeny. Gene 2001, 262:189-198.

46. Xu Y, Ishida H, Reisen D, Hanson MR: Upregulation of a tonoplast-localized cytochrome P450 during petal senescence in Petunia inflate. BMC Plant Biol 2006, 6:8

47. Melotto M, Kelly JD: Fine mapping of the Co-4 locus of common bean reveals a resistance gene candidate, COK-4, that encodes for a protein kinase. Theor Appl Genet 2001, 103:508-517.

48. Reis PA, Rosado GL, Silva LA, Oliveira LC, Oliveira LB, Costa MD, Alvim FC, Fontes EP: The binding protein BiP attenuates stress-induced cell death in soybean via modulation of the $\mathrm{N}$-rich protein-mediated signaling pathway. Plant Physiol 2011, 157:1853-1865

49. Vierling E: The role of heat shock proteins in plants. Ann Rev Plant Physio Plant Mol Biol 1991, 42:579-620

50. Brugiere S, Kowalski S, Ferro M, Seigneurin-Berny D, Miras S, Salvi D, Ravanel S, Herin P, Garin J, Bourguignon J, Joyard J, Rolland N: The hydrophobic proteome of mitochondrial membranes from Arabidopsis cell suspensions. Phytochemistry 2004, 65:1693-1707.

51. Davies E, Fillingham BD, Oto $Y$, Abe S: Evidence for the existence of cytoskeleton-bound polysomes in plants. Cell Biol Int Rep 1991, 15:973-981

52. Hicke L: A new ticket for entry into budding vesicles-ubiquitin. Cell 2001 106:527-530.

53. Schirmer EC, Florens L, Guan T, Yates JR, Gerace L: Nuclear membrane proteins with potential disease links found by subtractive proteomics. Science 2003, 301:1380-1382.

54. Masaki T, Mitsui N, Tsukagoshi H, Nishii T, Morikami A, Nakamura K: Activator of Spomin::LUC1/WRINKLED1 of Arabidopsis thaliana transactivates sugar-inducible promoters. Plant Cell Physiol 2005 46:547-556

55. Kato $Y$, Sun $X$, Zhang L, Sakamoto W: Cooperative D1 degradation in the photosystem II repair mediated by chloroplastic proteases in Arabidopsis. Plant Physiol 2012, 159:1428-1439. 
56. Olinares PD, Kim J, Van Wijk KJ: The Clp protease system; a central component of the chloroplast protease network. Biochim Biophys Acta 2011, 1807:999-1011.

57. Pang Q, Chen S, Dai S, Chen Y, Wang Y, Yan X: Comparative proteomics of salt tolerance in Arabidopsis thaliana and Thellungiella halophile. J Proteome Res 2010, 9:2584-2599.

58. Van Cutsem E, Simonart G, Degand H, Faber AM, Morsomme P, Boutry M: Gel-based and gel-free proteomic analysis of Nicotiana tabacum trichomes identifies proteins involved in secondary metabolism and in the (a)biotic stress response. Proteomics 2011, 11:440-454.

59. Mitra SK, Gantt JA, Ruby JF, Clouse SD, Goshe MB: Membrane proteomic analysis of Arabidopsis thaliana using alternative solubilization techniques. J Proteome Res 2007, 6:1933-1950.

60. Traas J, Monéger F: Systems biology of organ initiation at the shoot apex. Plant Physiol 2010, 152:420-427.

61. Vertommen A, Panis B, Swennen R, Carpentier SC: Evaluation of chloroform/methanol extraction to facilitate the study of membrane proteins of non-model plants. Planta 2010, 231:1113-1125.

62. Martinec J, Felt T, Scanlon CH, Lumsden PJ, Machavkova I: Subcellular localization of a high affinity binding site for D-myo-inositol 1,4,5triphosphate from Chenopodium rubrum. Plant Physiol 2000, 124:475-483.

63. Sze $\mathrm{H}: \mathrm{H}^{+}$-translocating ATPases: advances using membrane vesicles. Ann Rev Plant Physiol 1985, 36:175-208.

64. Ray PM, Shininger TL, Ray MM: Isolation of beta-glucan synthetase particles from plant cells and identification with Golgi membranes. Proc Natl Acad Sci USA 1969, 64:605-614.

65. Ames BN: Assay of inorganic phosphate, total phosphate and phosphatase. Methods Enzymol 1966, 8:115-118.

66. Ferro M, Seigneurin-Berny D, Rolland N, Chapel A, Salvi D, Garin J, Joyard J: Organic solvent extraction as a versatile procedure to identify hydrophobic chloroplast membrane proteins. Electrophoresis 2000, 21:3517-3526.

67. Tripathy BC, Chakraborty N: 5-aminolevulinic acid induced photodynamic damage to the photosynthetic electron transport chain of cucumber (Cucumis sativus L.) cotyledons. Plant Physiol 1991, 96:761-767.

68. Perkins DN, Pappin DJ, Creasy DM, Cottrell JS: Probability-based protein identification by searching sequence databases using mass spectrometry data. Electrophoresis 1999, 20:3551-3567.

69. Creasy DM, Cottrell JS: Error tolerant searching of uninterpreted tandem mass spectrometry data. Proteomics 2002, 2:1426-1434.

doi:10.1186/1477-5956-10-59

Cite this article as: Jaiswal et al.: Proteomic analysis reveals the diversity and complexity of membrane proteins in chickpea (Cicer arietinum L.).

Proteome Science 2012 10:59.

\section{Submit your next manuscript to BioMed Central and take full advantage of:}

- Convenient online submission

- Thorough peer review

- No space constraints or color figure charges

- Immediate publication on acceptance

- Inclusion in PubMed, CAS, Scopus and Google Scholar

- Research which is freely available for redistribution 